\title{
Oxidative stress in dogs
}

\section{Estresse oxidativo em cães}

\section{Claudia Russo $^{1 *}$; Ana Paula Frederico Rodrigues Loureiro Bracarense ${ }^{2}$}

\begin{abstract}
Reactive oxygen species (ROS), also known as free radicals, are generated during cellular respiration. Under normal conditions, the body has the ability to neutralize the effects of free radicals by using its antioxidant defenses. In the case of an imbalance between oxidants and antioxidants, free radical production exceeds the capacity of organic combustion, resulting in oxidative stress. Of all the cellular components compromised by the harmful effects of ROS, the cell membrane is the most severely affected owing to lipid peroxidation, which invariably leads to changes in the membrane structure and permeability. With lipid peroxidation of the cell membrane, some by-products can be detected and measured in tissues, blood, and other bodily fluids. The measurement of biomarkers of oxidative stress is commonly used to quantify lipid peroxidation of the cell membrane in humans, a species in which ROS can be considered as a cause or consequence of oxidative stress-related diseases. In dogs, few studies have demonstrated this correlation. The present review aims to identify current literature knowledge relating to oxidative stress diseases and their detection in dogs.
\end{abstract}

Key words: Oxidative stress. Lipid peroxidation. Free radicals. Dogs.

\section{Resumo}

Nos processos decorrentes da respiração celular, são gerados produtos denominados espécimes reativos de oxigênio (EROS), conhecidos também como radicais livres. Em condições normais, o organismo possui capacidade de neutralizar os efeitos dos radicais livres utilizando suas defesas antioxidantes. Em situações de desequilíbrio entre agentes oxidantes e antioxidantes, a produção de radicais livres excede a capacidade orgânica de neutralização, resultando na condição conhecida como estresse oxidativo. Dentre todos os componentes celulares atingidos pelos efeitos nocivos dos EROS, as membranas celulares são as estruturas mais severamente acometidas, devido à peroxidação lipídica, que leva, invariavelmente, a alterações estruturais e também na sua permeabilidade. Na peroxidação lipídica da membrana celular, alguns subprodutos podem ser detectados e mensurados nos tecidos, sangue e outros fluidos corpóreos. A mensuração de biomarcadores de estresse oxidativo é habitualmente utilizada para quantificar a lipoperoxidação da membrana celular em humanos, espécie onde as EROS podem ser consideradas como causa ou consequência de doenças relacionadas ao estresse oxidativo. Nos cães, alguns poucos estudos demonstram essa correlação. A presente revisão tem como principal objetivo verificar na literatura, onde se encontra atualmente o conhecimento relacionando o estresse oxidativo às doenças em cães bem como as possíveis formas de detecção de biomarcadores na espécie canina.

Palavras-chave: Estresse oxidativo. Lipoperoxidação. Radicais livres. Cães.

\footnotetext{
${ }^{1}$ M.e, Discente do Programa de Pós-Graduação em Ciência Animal da Universidade Estadual de Londrina, UEL, Londrina, PR, Brasil. E-mail: russo.claudia@hotmail.com

2 Prof $^{\mathrm{a}} \mathrm{Dr}^{\mathrm{a}}$ Associada, Departamento de Medicina Veterinária Preventiva, UEL, Londrina, PR. E-mail: anapaula@uel.br

* Autor para correspondência
} 


\section{Introduction}

The effects of free radicals and oxidative stress on tissues and cells have been a leading topic in a significant number of studies in human medicine for over 40 years (SALVADOR; HENRIQUES, 2004). More recently, this subject has been gaining ground in veterinary medicine. There are many possibilities for conducting research on the correlation of oxidative stress to diseases. Free radical production during physical activity and its effect on the animal body (ARAUJO et al., 2010), the use of antioxidants, and methods for detection and quantification of oxidative stress are a few examples. It is a vast field yet to be explored in veterinary sciences. The aim of this review is to provide the veterinarian with an overview of the topic, addressing dogs in particular.

\section{Development}

During cellular respiration, oxygen, the key element required to produce energy for the cellular metabolism and oxidation of organic compounds, is consumed and reduced, generating a series of highly reactive chemical substances called reactive oxygen species (ROS), also known as free radicals (DALLAQUA; DAMASCENO, 2011). The term "free radical" is used to describe a highly reactive molecule or atom, having one or more unpaired electron in the last electron layer. At high concentrations, ROS can interact with the biomolecules that are present in tissues, cell membranes, and organelles, causing cell injury (VALKO et al., 2007). Under normal conditions, the organism is able to neutralize the effects of the free radicals by using its antioxidant defenses. However, in situations of imbalance between oxidant and antioxidant agents, the production of free radicals exceeds the neutralizing capacity of organic compounds, resulting in oxidative stress (HALLIWELL; GUTTERIDGE, 1996).

Of all the cellular components compromised by the harmful effects of ROS, cell membranes are the most severely affected owing to lipid peroxidation, which invariably leads to alterations in the membrane structure and permeability (FERREIRA; MATSUBARA, 1997). The quantification of ROS generated during oxidative stress is questionable owing to their very low concentrations and the high speed at which they react with other biomolecules. Therefore, attempts to measure oxidative stress are based on the indirect measurement of the effects of ROS; that is, in the measurement of its by-products after reaction with biomolecules (FLOYD, 1990).

During lipid peroxidation of cell membranes, certain by-products can be detected and measured in tissues, blood, and other bodily fluids. Determination of malondialdehyde (MDA) in the serum is commonly used to quantify the lipid peroxidation of cell membranes in living organisms, where the ROS are seen as a cause or consequence of diseases related to oxidative stress (FERREIRA; MATSUBARA, 1997).

Human medical research has been studying free radicals and oxidative stress and their effects on the living organism for many years. Studies in this area have increased greatly since the 1970s. Initially, emphasis was given to understanding the harmful effects of ionizing radiation. It was found that the energy released by this type of radiation leads to changes in the orbits of electrons, making the atoms, especially oxygen, highly reactive, leading to the formation of molecules such as molecular oxygen and hydrogen peroxide $\left(\mathrm{H}_{2} \mathrm{O}_{2}\right)$, which are considered free radicals (SALVADOR; HENRIQUES, 2004). Currently, the association between oxidative stress and diseases such as cancer, atherosclerosis, fibromyalgia, and autoimmune disorders, in addition to aging-related processes, is well established (HALLIWELL; GUTTERIDGE, 1996; FINKEL; HOLBROOK, 2000; BAGIS et al., 2005). In dogs or other domestic animals of interest to veterinary medicine, studies on these associations are recent and still scarce (GALVÃO, 2009). 


\section{Reactive oxygen species}

It can be said that ROS are present in all biological systems. During aerobic cellular metabolism under physiological conditions, oxygen undergoes tetravalent reduction by accepting four electrons, which results in the formation of water $\left(\mathrm{H}_{2} \mathrm{O}\right)$ and other reactive intermediate compounds, such as the radicals superoxide $\left(\mathrm{O}_{2}^{-}\right)$, hydroxyl $(\bullet \mathrm{OH})$, and $\mathrm{H}_{2} \mathrm{O}_{2}(\mathrm{COHEN}, 1989) . \mathrm{O}_{2}^{-}$occurs in almost all aerobic cells and is produced during the activation of neutrophils, monocytes, eosinophils, and macrophages. Although it is considered to be only mildly reactive, some secondary biological lesions have been observed in systems that generate $\mathrm{O}_{2}^{-}$. The protonated superoxide radical (i.e., with a hydrogen radical; termed a "hydroperoxyl radical") seems to be much more reactive than $\mathrm{O}_{2}$, since it demonstrates the ability to easily induce damage in biological membranes (HALLIWELL; GUTTERIDGE, 1990). The radical $\bullet \mathrm{OH}$ is considered to be the most reactive of all ROS in biological systems. It can rapidly combine with other radicals or metals at the site where it was produced, leading to DNA deactivation or mutations, inactivation of proteins, and oxidation of fatty acids in cell membranes (HALLIWELL; GUTTERIDGE, 1996). Although $\mathrm{H}_{2} \mathrm{O}_{2}$ is not considered a free radical per se, it is very harmful because it does not have an unpaired electron. This is due to it being directly associated with the production of $\cdot \mathrm{OH}$, which is highly toxic to the cell. In addition to having a long half-life, $\mathrm{H}_{2} \mathrm{O}_{2}$ is capable of crossing lipid layers and binding to proteins bound to iron, as occurs in erythrocytes, and therefore its toxicity increases in the presence of iron (EATON, 1991).

Elements such as metals (particularly iron, which exists in abundance in the body) have been reported to be catalysts of oxidative damage. The use of iron chelating agents has been indicated for certain diseases, such as head trauma in humans (HALLIWELL, 1992). Other products derived from nitrogen (reactive nitrogen species (RNS)), sulfur, copper, and manganese may also be considered free radicals in biological systems and can be associated with cell damage through oxidative stress (VASCONCELOS et al., 2007).

\section{Biomarkers of oxidative stress}

The result of the reactions of ROS and RNS with biomolecules is the formation of substances that can be used as markers of oxidative damage. Currently, numerous studies are being conducted to validate the biomarkers of oxidative stress. There is also uncertainty over which of the available biomarker detection methods is the most accurate, or the more specific, for the different types of oxidative damage, making it difficult to obtain absolute reference values for specific markers in living systems (MACOTPET et al., 2013). Furthermore, in healthy humans, genetic, nutritional, environmental, and even cultural factors may change the redox balance (balance between oxidizing reactive species and the antioxidant system) of a population (KADIISKA et al., 2005).

Despite this fact, some biomarkers are already routinely used. The ROS by-products can be detected directly through electron paramagnetic resonance, but the cost and technical requirements hamper its routine use (FERREIRA; MATSUBARA, 1997). The methods most widely used nowadays detect the action of ROS indirectly, either by measuring the products generated from its action on biomolecules or by measuring the quality and quantity of antioxidants, thereby evaluating oxidative damage (MAK, 2008). Most commonly used are the spectrophotometric and chromatographic methods that measure the activity of antioxidant enzymes, such as superoxide dismutase (SOD), catalase (CAT), and glutathione peroxidase. SOD catalyzes the dismutation of $\mathrm{O}_{2}^{-}$to $\mathrm{H}_{2} \mathrm{O}_{2}$; CAT acts by decomposing $\mathrm{H}_{2} \mathrm{O}_{2}$ to $\mathrm{H}_{2} \mathrm{O}$ and $\mathrm{O}_{2}$; and glutathione peroxidase acts on peroxides in general. These enzymes are considered components of the enzymatic antioxidant system. 
A series of non-enzymatic substances are also part of the antioxidant system. In the extracellular medium (serum and plasma), several non-enzymatic antioxidant agents (e.g., vitamin C, vitamin E, and $\beta$-carotene) can be found. Some authors support the idea of measuring antioxidant substances as a way to assess the presence of oxidative damage, using the total antioxidant capacity (TAC) method, which considers the cumulative action of all antioxidants present. Other authors suggest that this method is not the best, since an increase in TAC is not necessarily desirable, as the antioxidant enzymes are not always decreased in disease conditions (PRIOR; CAO, 1999). On the other hand, detection of the presence of oxidative stress can be performed through measurement of biomarkers for the damage caused by ROS, RNS, and other radicals, such as MDA, isoprostanes, lipoperoxides, and other derivatives of lipid peroxidation of cell membranes.

MDA is currently regarded as a general biomarker of oxidative damage in the plasma (KADIISKA et al., 2005). As a product of lipid peroxidation of cell membranes, its quantification in biological systems is an important parameter for the assessment of cellular oxidative stress (PILZ et al., 2000; SIM et al., 2003). Andrade Júnior (2005) and Del Rio et al. (2005) inferred that MDA is highly cytotoxic and genotoxic, and should be considered more than just a biomarker of oxidative damage, owing to its interaction with DNA and other proteins. High levels of MDA are routinely used as a way to detect oxidative stress in several human diseases, such as systemic lupus erythematosus, diabetes, pulmonary diseases, Alzheimer's disease, and cancer, which allow us to have funding for the research in animals (FERREIRA; MATSUBARA, 1997; ANDRADE JÚNIOR, 2005; PÉREZ et al., 2012). The most widely used technique for measuring MDA is the thiobarbituric acid reactive substances (TBARS) assay. This technique quantifies products generated from substances reactive to barbituric acid, among which MDA is the main component. However, the technique has low sensitivity and specificity for the detection of aldehydes in biological fluids, which has justified the search for other techniques with higher fidelity (ABDALLA; SENA, 2008).

Nowadays, other biomarkers of lipid peroxidation, such as isoprostanes and acrolein, are also considered as important for determining oxidative damage in humans and, more recently, in animals (LIMA; ABDALLA, 2001; MARQUIS et al., 2015)

\section{Oxidative stress and related diseases}

There are currently lines of scientific evidence showing that many diseases are related to the oxidative stress caused by ROS or RNS. The most severe damages are the ones affecting the DNA or RNA of the cell. When a break occurs in the DNA strand, it can reconnect in another position, changing the order of its bases. This event is one of the processes causing mutation, which can be related to oncogenesis. Likewise, changing the sequence of the amino acids of a protein that act as an enzyme can lead to a loss of or change in its function (BARREIROS et al., 2006).

Lipid peroxidation in cell membranes affects the active and passive transport systems and can lead to rupture of the membrane and subsequent cell death. When lipid peroxidation occurs in the blood, it aggravates the vessel walls, favoring the accumulation of lipids, which can trigger atherosclerosis, stroke, infarction, or cerebrovascular events (BARREIROS et al., 2006). Some studies have been performed on specific types of neoplasms in humans in search for information on the behaviors of ROS and their relationship with diseases. In a study comparing the intestinal mucosa of healthy individuals with those of colorectal cancer patients, the levels of oxidative damage to the DNA were shown to be significantly higher in the patients with the neoplasm. Interestingly, the normal tissue also had some level of oxidative damage, demonstrating the importance of ROS in the initial 
aggression to the intestinal mucosa (RIBEIRO et al., 2007). Another study demonstrated the presence of oxidative stress in women with breast cancer through the evaluation of TAC levels, which were lower than the levels found in healthy women. The serum MDA levels were also higher than those of the control group (SENER et al., 2007).

In veterinary oncology, oxidative stress in canine lymphoma is also detected via MDA and isoprostane quantification, in addition to determination of the concentrations of antioxidants agents such as vitamin $\mathrm{E}$ and glutathione peroxidase (WINTER et al., 2009). A significant increase in MDA and a decrease in TAC were observed in 24 canine patients with multicentric lymphoma (MACEDO, 2010). In another study, dogs with multicentric lymphoma showed a significant association between the presence of anemia and oxidative stress, detected through the quantification of glutathione reductase and peroxidase, and the TAC (UBUKATA, 2010). Recently, a study compared the levels of MDA between a group of 101 healthy dogs and a group of 80 dogs with different neoplasms, and observed significantly higher levels in the dogs with cancer, suggesting that these animals were under oxidative stress (MACOTPET et al., 2013). In that study, the serum MDA concentration was determined by the TBARS method; that is, by the determination in the serum of substances reactive to barbituric acid, where the MDA is the main component. Several studies have also indicated the relationship between oxidative stress and the development of mammary tumors in dogs, mainly by correlating serum and tissue MDA values using the TBARS technique, as well as thelevels of antioxidants such as vitamin Eand vitamin C (SZCZUBIAL et al., 2004; FRANCISCO NETO et al., 2005; KUMARAGURUPARAN et al., 2005; ASKAR et al., 2009; GALVÃO, 2009). Askar et al. (2009) demonstrated increased concentrations of MDA and nitric oxide (NO) and decreased serum concentrations of vitamin $\mathrm{C}$ (considered to be the first line of antioxidant defense) in 10 dogs with malignant breast neoplasms. According to this author, in addition to the oxidative stress detected, the decrease of antioxidant defenses such as vitamin $\mathrm{C}$ could be related to carcinogenesis.

The protective effect of natural substances considered antioxidant and cytoprotective was evaluated in cultured canine aortic endothelial cells, submitted to the oxidative action of $\mathrm{H}_{2} \mathrm{O}_{2}$ (RIPOLL et al., 2012). In that study, the authors confirmed the beneficial effectiveness of taurine and L-carnitine, both antioxidant agents already in use for the treatment of canine cardiopathies, and also of isoflavone from soy and pomegranate extract. Since the presence of oxidative stress in canine cardiopathies has already been established (FREEMAN et al., 2005), it is useful to determine the efficacy of natural substances having antioxidant capacity like the ones studied above, so that they can be included and prescribed as part of the treatment of canine heart diseases. In veterinary medicine, oxidative stress has also been linked with kidney disease (GALVÃO, 2009). The TAC between healthy dogs and dogs with prerenal azotemia was compared, showing that the diseased dogs had a lower antioxidant capacity. Moreover, in these animals, there was an acceleration of neutrophil apoptosis, confirming the existence of oxidative stress in azotemic dogs (SILVA et al., 2013). On the other hand, oxidative metabolism should occur in a physiological manner and is part of the immune response against antigens. For example, after the phagocytosis of microorganisms, it is expected that normal neutrophils will lead the microbial cells to death via the action of lysosomal enzymes and oxidizing agents. An ex vivo study showed that neutrophils from healthy dogs, exposed to the serum of uremic dogs suffering from renal failure, experienced a significant decrease in their oxidative metabolism, due to changes in $\mathrm{O}_{2}^{-}$production, leading to an impairment of innate immunity. This was similar to what occurs in humans with chronic kidney failure, a situation in which the inhibition of ROS production is harmful to the body (BARBOSA et al., 2010). 
The association between oxidative stress and ischemia-reperfusion injury has been extensively discussed in human medicine (SILVA JÚNIOR et al., 2002; KUNZ et al., 2010; SILVA et al., 2013), primarily with the aim to determine the effectiveness of substances with antioxidant potential that can be included in therapeutic procedures. Natural substances containing phenolic derivatives, such as flavonoids, minimize oxidative damage by inhibiting the action of free radicals, preventing lipid peroxidation, and therefore improving endothelial and neuroprotective functions (MENDES, 2012). It should also be mentioned here that a recent study observed an increase in the concentrations of isoprostanes and acrolein in the spinal cord of dogs with post-traumatic myelomalacia, confirming the nerve degeneration was due to oxidative stress, similar to what occurs in humans with recurrent neurodegeneration of the spinal cord after injury (MARQUIS et al., 2015).

Other infections, including cutaneous conditions such as demodicosis, can also be related to oxidative stress (ROMANUCCI et al., 2011). According to authors who observed decreased levels of endogenous antioxidants (e.g., glutathione peroxidase, CAT, copper, and zinc) in dogs with localized and generalized demodicosis, the disease is related to the occurrence of oxidative stress, suggesting supplementation with antioxidants as part of the diet (DIMRI et al., 2008). In another study, the presence of oxidative stress in the eyeball of dogs with cataracts after phacoemulsification was compared between a group with intraocular lens implant and a group without lens implant. It was found through quantitative determination of proteins in the aqueous humor and evaluation of total antioxidant activity (also in the aqueous humor) that the presence of the implanted lens contributed to the occurrence of oxidative stress in the intraocular space (LIMA, 2003).

In the field of reproduction, several studies have sought to relate oxidative stress with fertility, by identifying and quantifying the antioxidant substances in the seminal plasma of fertile and sub-fertile dogs, in addition to analyzing the possible beneficial effects of supplementing the diet with antioxidants (ANDRADE et al., 2010; LOPES et al., 2011). Another study, also in the field of reproduction, compared the antioxidant activity and serum concentrations of biomarkers of oxidative damage in dogs subjected to an ovariohysterectomy surgery. That study found a significant increase in the concentrations of substances reactive to barbituric acid (TBARS) even after several days post-operation, suggesting that these dogs would be more susceptible to diseases related to oxidative stress (SZCZUBIAL et al., 2015).

Nonpathological conditions in which oxidative stress can occur should also be considered. A significant increase in the levels of the antioxidant glutathione peroxidase enzyme was observed in dogs submitted to intense exercise for a short period of time (POLIZEL, 2011). In that study, the increased levels of glutathione peroxidase were related to an increased production of free radicals, a secondary effect of the higher oxygen consumption by the body during physical exertion.

\section{Conclusion}

The measurement of biomarkers of oxidative stress or even of antioxidant substances in the serum or tissues may lead to new findings from studies that show the relationship between free radicals and diseases, either as a cause, or as an effect, of pathological conditions. The importance of the use of antioxidants as adjuvant treatment that aims to minimize oxidative damage can also be studied in canine medicine. Studies that seek to standardize laboratory techniques and the definition of parameters that can be used as references in different types of veterinary medicine may be of great use. This knowledge could contribute both to basic research and to therapeutic targeting in the routine clinical setting. 


\section{References}

ABDALLA, D. S. P.; SENA, K. C. M. Biomarcadores de peroxidação lipídica na aterosclerose. Revista de Nutrição, Campinas, v. 21, n. 6, p. 749-756, 2008.

ANDRADE, E. R.; MELO-STERZA, F. A.; SENEDA, M. M.; ALFIERI, A. A. Consequências da produção de espécies reativas de oxigênio na reprodução e principais mecanismos antioxidantes. Revista Brasileira de Reprodução Animal, Belo Horizonte, v. 34, n. 2, p. 7985, 2010.

ANDRADE JÚNIOR, D. R. Os radicais livres de oxigênio e as doenças pulmonares. Jornal Brasileiro de Pneumologia, Brasília, v. 31, n. 1, p. 60-68, 2005.

ARAUJO, M. B.; VOLTARELLI, F. A.; MANCHADOGOBATTO, F. B.; MOURA, L. P.; MELLO, M. A. R. Treinamento em diferentes intensidades e biomarcadores de estresse oxidativo e do metabolismo glicídico musculo-esquelético de ratos. Revista da Educação Física, Maringá, v. 21, n. 4, p. 695-707, 2010.

ASKAR, T. K.; SALMANOGLU, B.; SALMANOGLU, R.; ERKAL, N.; BESKAYA, A. Changes in oxidative status and trace element levels in dogs with mammary tumours. Acta Veterinaria, Belgrado, v. 59, n. 4, p. 405411, 2009.

BAGIS, S.; TAMER, L.; SAHIN, G.; BILGIN, R.; GULER, H.; ERCAN, B.; ERDOGAN, B. E. C. Free radicals and antioxidants in primary fibromyalgia: an oxidative stress disorder? Rheumatology International, Berlin, v. 25, n. 3, p. 188-190, 2005.

BARBOSA, T. S.; MORI, C. K.; CIARLINI, P. C. Efeito inibidor do soro urêmico sobre o metabolismo oxidativo dos neutrófilos de cães. Arquivo Brasileiro de Medicina Veterinária e Zootecnia, Belo Horizonte, v. 62, n. 6, p. 1352-1358, 2010.

BARREIROS, A. L. B. S.; DAVID, J. M.; DAVID, J. P. Estresse oxidativo: relação entre geração de espécies reativas e defesas do organismo. Química Nova, São Paulo, v. 29, n. 1, p. 113-123, 2006.

COHEN, M. V. Free radicals in schemic and reperfusion myocardial injury: is this time for clinical trials? Annals of Internal Medicine, Philadelphia, v. 111, n. 11, p. 918931, 1989.

DALLAQUA, B.; DAMASCENO, D. C. Comprovação do efeito antioxidante de plantas medicinais utilizadas no tratamento do diabetes mellitus em animais: artigo de atualização. Revista Brasileira de Plantas Medicinais, Botucatu, v. 13, n. 3, p. 367-337, 2011.

DEL RIO, D.; STEWART, A. J.; PELLEGRINI, N. A review of recent studies on malondialdehyde as toxic molecule and biological marker of oxidative stress metabolism and cardiovascular. Nutrition, Metabolism, and Cardiovascular Diseases, New York, v. 15, n. 4, p. 316-328, 2005.

DIMRI, U.; RANJAN, R.; KUMAR, N.; SHARMA, M. C.; SWARUP, D.; SHARMA, B.; KATARIA, M. Changes in oxidative stress indices, zinc and copper concentrations in blood in canine demodicosis. Veterinary Parasitology, New York, v. 154, n. 1-2, p. 98-102, 2008.

EATON, J. W. Catalases, peroxidases, glutathione and hydrogen peroxide: mysteries of the bestiary. Journal of Laboratory and Clinical Medicine, Amsterdam, v. 118, n. 1, p. 3-4, 1991.

FERREIRA, A. L. A.; MATSUBARA, L. S. Radicais livres: conceitos, doenças relacionadas, sistema de defesa e estresse oxidativo. Revista da Associação Médica Brasileira, São Paulo, v. 43, n. 1, p. 61-68, 1997.

FINKEL, T.; HOLBROOK, N. J. Oxidants, oxidative stress and the biology of ageing. Nature, London, v. 408, n. 6809 , p. 239-247, 2000.

FLOYD, R. A. Role of oxygen free radicals in carcinogenesis and brain ischemia. FASEB Journal, New York, v. 4, n. 9, p. 2587-2597, 1990.

FRANCISCO NETO, A.; SILVA, J. C. C. B.; FAGUNDES, D. J.; PERCÁRIO, S.; NOVO, N. F.; JULIANO, Y.; MOREIRA NETO, A. A. Estudo das alterações oxidativas, da capacidade antioxidante total e do óxido nítrico, em ratos submetidos à isquemia e reperfusão de membros posteriores. Acta Cirúrgica Brasileira, São Paulo, v. 20, n. 2, p. 48-56, 2005.

FREEMAN, L. M.; RUSH, J. E.; MILBURY, P. E.; BLUMBERG, J. B. Antioxidant status and biomarkers of oxidative stress in dogs with congestive heart failure. Journal of Veterinary Internal Medicine, Lakewood, v. 19, n. 4, p. 537-541, 2005.

GALVÃO, A. L. B. Estresse oxidativo nos estágios finais da doença renal crônica em pequenos animais. Archives of Veterinary Science, Curitiba, v. 14, n. 3, p. 178-186, 2009.

HALLIWELL, B. Reactive oxygen species and the central nervous system. Journal of Neurochemistry, Oxford, v. 59, n. 5, p. 1609-1623, 1992.

HALLIWELL, B.; GUTTERIDGE, J. M. Oxygen free radicals and iron in relation to biology and medicine: some problems and concepts. Archives of Biochemistry and Biophysics, New York, v. 246, n. 2, p. 501-514, 1996.

Role of free radicals and catalytic metal ions in human disease: an overview. Methods in Enzymology, New York, v. 186, n. 1, p. 1-85, 1990. 
KADIISKA, M. B.; GLADEN, B. C.; BAIRD, D. D.; GERMOLEC, D.; GRAHAM, L. B.; PARKER, C. E.; NYSKA, A.; WACHSMAN, J. T.; AMES, B. N.; BASU, S.; BROT, N.; FITZGERALD, G. A.; FLOYD, R. A.; GEORGE, M.; HEINECKE, J. W.; HATCH, G. E.; HENSLEY, K.; LAWSON, J. A.; MARNETT, L. J.; MORROW, J. D.; MURRAY, D. M.; PLASTARAS, J.; ROBERTS II, L. J.; ROKACH, J.; SHIGENAGA, M. K.; SOHAL, R. S.; SUN, J.; TICE, R. R.; VAN THIEL, D. H.; WELLNER, D.; WALTER, P. B.; TOMER, K. B.; MANSON, R. P.; BARRETT, J. C. Biomarkers of oxidative stress study II: are oxidation products of lipids, proteins and DNA markers of $\mathrm{CCl}_{4}$ poisoning? Free Radical Biology and Medicine, New York, v. 38, n. 6, p. 698-710, 2005.

KUMARAGURUPARAN, R.; BALACHANDRAN, C.; MANOHAR, B. M.; NAGINI, S. Altered oxidantantioxidant profile in canine mammary tumours. Veterinary Research Communications, New York, v. 29, n. 4, p. 287-296, 2005.

KUNZ, A.; DIRNAGL, U.; MERGENTHALER, P. Acute pathophysiological processes after ischaemic and traumatic brain injury. Best Practice \& Research: Clinical Anaesthesiology, Berlin, v. 24, n. 4, p. 495-509, 2010.

LIMA, A. L. Estudo comparative de estresse oxidative após facoemulsificação experimental com e sem implante de lentes intra-oculares em cães. 2003. Dissertação (Mestrado em Cirurgia) - Faculdade de Medicina Veterinária e Zootecnia. Universidade de São Paulo, São Paulo.

LIMA, E. S.; ABDALLA, D. S. P. Peroxidação lipídica: mecanismos e avaliação em amostras biológicas. Revista Brasileira de Ciências Farmacêuticas, São Paulo, v. 37, n. 3, p. 293-303, 2001.

LOPES, B. V.; MONTEIRO, G. A.; OVÍDIO, P. P.; JORDÃO JÚNIOR, A. A.; LOPES, M. D. Avaliação do estresse oxidativo no plasma seminal de cães férteis e subférteis após suplementação oral com vitamina $\mathrm{C}$ e $\mathrm{E}$. Veterinária e Zootecnia, São Paulo, v. 18, n. 3, p. 452461, 2011.

MACEDO, T. R. Avaliação das concentrações de superóxido dismutase e da fragilidade osmótica eritrocitária em cães com linfoma multicêntrico com e sem anemia. 2010. Dissertação (Mestrado em Clínica Veterinária) - Faculdade de Medicina Veterinária e Zootecnia. Universidade de São Paulo, São Paulo.

MACOTPET, A.; SUKSAWAT, F.; SUKON, P.; PIMPAKDEE, K.; PATTARAPANWICHIEN, E.; TANGRASSAMEEPRASERT, R.; BOONSIRI, P. Oxidative stress in cancer-bearing dogs assessed by measuring serum malondialdehyde. BMC Veterinary Research, New York, v. 9, n. 101, p. 101-105, 2013.

MAK, J. C. Pathogenesis of COPD. Part II. Oxidativeantioxidative imbalance. The International Journal of Tuberculosis and Lung Disease, Paris, v. 12, n. 4, p. 368 374, 2008.

MARQUIS, A.; PACKER, R. A.; BORGENS, R. B.; DUERSTOCK, B. S. Increase in oxidative stress biomarkers in dogs with ascending-descending myelomalacia following spinal cord injury. Journal of the Neurological Sciences, Amsterdam, v. 353, n. 1-2, p. 63-69, 2015.

MENDES, F. F. Efeito neuroprotetor do extrato etanólico da casca de pequi em lesões de isquemia e reperfusão cerebral de ratas submetidas a dieta hipercalórica. 2012. Dissertação (Mestrado em Ciência Animal) - Programa de Pós-Graduação em Ciência Animal. Escola de Veterinária e Zootecnia. Universidade Federal de Goiás, Goiânia.

PÉREZ, G. Y.; PÉREZ, L. C. G.; NETTO, R. C. M.; LIMA, D. S. N.; LIMA, E. S. Malondialdeído e grupo sulfidrila como biomarcadores do estresse oxidativo em pacientes com lúpus eritematoso sistêmico. Revista Brasileira de Reumatologia, Campinas, v. 52, n. 4, p. 656-660, 2012.

PILZ, J.; MEINEKE, I.; GLEITER, CH. Measurement of free and bound malondialdehyde in plasma by high performance liquid chromatography as the 2,4-dinitrophenylhydrazine derivative. Journal of Chromatography. B, Biomedical Sciences and Applications, Amsterdam, v. 742, n. 2, p. 315-325, 2000.

POLIZEL, A. Avaliação laboratorial do estresse oxidativo e eletrocardiografia de cadelas submetidas a exercício. 2011. Dissertação (Mestrado em Clínica Veterinária) - Programa de Pós-Graduação em Ciência Animal. Universidade do Oeste Paulista, Presidente Prudente.

PRIOR, R. L.; CAO, G. In vivo total antioxidant capacity: comparison of different analytical methods. Free Radical Biology \& Medicine, Elmsford, v. 27, n. 11-12, p. 11731181, 1999.

RIBEIRO, M. L.; PRIOLLI, D. G.; MIRANDA, D. D. C.; PAIVA, D. A.; PEDRAZZOLI JÚNIOR, J.; MARTINEZ, C. A. R. Avaliação do dano oxidativo ao DNA de células normais e neoplásicas da mucosa cólica de doentes com câncer colorretal. Revista Brasileira de Coloproctologia, Rio de Janeiro, v. 27, n. 4, p. 391-402, 2007.

RIPOLL, C.; COUSSAERT, A.; WALDENBERGER, F. R.; VISCHER, C.; GINOUVÈS, A.; MCGAHIE, D.; GATTO, H. Evaluation of natural substances' protective 
effects against oxidative stress in a newly developed canine endothelial cell-based assay and in cell-free radical scavenging assays. International Journal of Applied Research in Veterinary Medicine, Apopka, v. 10, n. 2, p. 113-124, 2012.

ROMANUCCI, M.; BONGIOVANNI, L.; RUSSO, A.; CAPUCCINI, S.; MECHELLI, L.; ORDEIX, L.; SALDA, L. D. Oxidative stress in the pathogenesis of canine zincresponsive dermatosis. Veterinary Dermatology, Malden, v. 22, n. 1, p. 31-38, 2011.

SALVADOR, M.; HENRIQUES, J. A. P. Radicais livres e a resposta celular ao estresse oxidativo. Canoas: Editora da ULBRA, 2004. 204 p.

SENER, D. E.; GÖNENÇ, A.; AKINCI, M.; TORUN, M. Lipid peroxidation and total antioxidant status in patients with breast cancer. Cell Biochemistry and Function, Chichester, v. 25, n. 4, p. 377-382, 2007.

SILVA, A. C. R. A.; ALMEIDA, B. F. M.; SOEIRO, C. S.; FERREIRA, W. L.; LIMA, V. M. F.; CIARLINI, P. C. Estresse oxidativo e aumento da apoptose em neutrófilos de cães com azotemia pré-renal. Arquivo Brasileiro de Medicina Veterinária e Zootecnia, Belo Horizonte, v. 65, n. 1, p. 163-170, 2013.

SILVA JÚNIOR, O. C.; CENTURION, S.; PACHECO, E. G.; BRISOTTI, J. L.; OLIVEIRA, A. F.; SASSO, K. D. Aspectos básicos da lesão de isquemia e reperfusão e do pré-condicionamento isquêmico. Acta Cirúrgica Brasileira, São Paulo, v. 17, n. 3, p. 96-100, 2002.

SIM, A. S.; SALONIKAS, C.; NAIDOO, D.; WILCKEN, D. E. Improved method for plasma malondialdehyde measurement by high-performance liquid chromatography using methyl malondialdehyde as an internal standard. Journal of Chromatography. B, Analytical Technologies in the Biomedical and Life Sciences, Amsterdam, v. 785, n. 2, p. 337-344, 2003.
SZCZUBIAL, M; KANKOFER, M.; BOCHNIARZ, M.; DABROWSKI, R. Effects of ovariohysterectomy on oxidative stress markers in female dogs. Reproduction in Domestic Animals, Berlin, v. 50, n. 3, p. 393-399, 2015.

SZCZUBIAL, M.; KANKOFER, M.; ŁOPUSZYŃSKI, W.; DABROWSKI, R.; LIPKO, J. Oxidative stress parameters in bitches with mammary gland tumours. Journal of Veterinary Medicine. A, Physiology, Pathology, Clinical Medicine, Berlin, v. 51, n. 7-8, p. 336-340, 2004.

UBUKATA, R. Avaliação do estado oxidante / antioxidante sistêmico e das defesas antioxidantes eritrocitárias em cães com linfoma multicêntrico com e sem anemia. 2010. Dissertação (Mestrado em Ciências) Departamento de Clínica Médica. Faculdade de Medicina Veterinária e Zootecnia. Universidade de São Paulo, São Paulo.

VALKO, M.; LEIBFRITZ, D.; MONCOL, J.; CRONIN, M. T. D.; MAZUR, M.; TELSER, J. Free radicals and antioxidants in normal physiological functions and human disease. The International Journal of Biochemistry \& Cell Biology, Oxford, v. 39, n. 1, p. 44-84, 2007.

VASCONCELOS, S. M. L.; GOULART, M. O. F.; MOURA, J. B. F.; MANFREDINI, V.; BENFATO, M. S.; KUBOTA, L. T. Espécies reativas de oxigênio e de nitrogênio, antioxidantes e marcadores de dano oxidativo em sangue humano: principais métodos analíticos para sua determinação. Quimica Nova, São Paulo, v. 30, n. 5, p. 1323-1338, 2007.

WINTER, J. L.; BARBER, L. G.; FREEMAN, L.; GRIESSMAYR, P. C.; MILBURY, P. E.; BLUMBERG, J. B. Antioxidant status and biomarkers of oxidative stress in dogs with lymphoma. Journal of Veterinary Internal Medicine, Philadelphia, v. 23, n. 2, p. 311-316, 2009. 
